University of Pennsylvania Carey Law School

Penn Law: Legal Scholarship Repository

Faculty Scholarship at Penn Law

2019

\title{
Measuring Norms and Normative Contestation: The Case of International Criminal Law
}

\author{
Beth A. Simmons \\ University of Pennsylvania Carey Law School \\ Hyeran Jo \\ Texas A \& M University - College Station
}

Follow this and additional works at: https://scholarship.law.upenn.edu/faculty_scholarship

Part of the Courts Commons, Criminal Law Commons, Criminology and Criminal Justice Commons, Human Rights Law Commons, International Humanitarian Law Commons, International Law Commons, and the Law and Society Commons

\section{Repository Citation}

Simmons, Beth A. and Jo, Hyeran, "Measuring Norms and Normative Contestation: The Case of International Criminal Law" (2019). Faculty Scholarship at Penn Law. 2055.

https://scholarship.law.upenn.edu/faculty_scholarship/2055

This Article is brought to you for free and open access by Penn Law: Legal Scholarship Repository. It has been accepted for inclusion in Faculty Scholarship at Penn Law by an authorized administrator of Penn Law: Legal Scholarship Repository. For more information, please contact PennlawIR@law.upenn.edu. 
[PUBLICATION INFORMATION: Journal of Global Security Studies, 4:1 (January 2019). 18-36.

\title{
Measuring Norms and Normative Contestation:
}

\author{
The Case of International Criminal Law
}

\author{
Beth A. Simmons \\ University of Pennsylvania \\ Simmons3@law.upenn.edu \\ Hyeran Jo \\ Texas A\&M \\ hyeranjo@tamu.edu
}

\begin{abstract}
:
One way to tell if an international norm is robust is to assess the breadth of its support from a wide variety of important actors. We argue that to assess norm robustness, we should look at the general beliefs, rhetorical support, and actions of both primary and secondary norm addressees (states and non-state actors) at various levels: international, regional, domestic and local. By way of example, we evaluate the robustness of international criminal law (ICL) norms by looking at the rhetoric and actions of a diverse set of international actors, including not only states and intergovernmental organizations but also ordinary publics, rebel groups, and non-governmental organizations. Assessing evidence of norms beyond states leads us to conclude that the core ICL norms are robust but their practical and institutional applicability are still contested. Contestation over applicability is important and there are hints that it is growing, at least among some key actors, suggesting the possibility of ICL norm decay.
\end{abstract}

Key words: norms, international criminal law, international humanitarian law, international criminal court, security and human rights 


\section{Measuring Norms and Normative Contestation:}

\section{The Case of International Criminal Law}

One of the most salient areas of normative flux in the past few decades has been the growing sense that individuals should be held accountable for egregious human rights violations. We see growing attention to this issue in discussions ranging from torture to child soldiering; from sexual violence to election violence. International criminal law (ICL) takes on some of these salient issues. ICL is the body of law that specifies individual criminal responsibility for “international crimes" - especially crimes against humanity, war crimes, and genocide (Cassese 2013, Bassiouni 2013). ${ }^{1}$ This individual criminal accountability and no impunity norm constitute core ICL norms.

There is wide agreement on three categories of such crimes: genocide, crimes against humanity, and war crimes, as evidenced by the criminal jurisdiction of a broad range of international, national, and hybrid tribunals. Genocide is defined in Article 2 of the Convention on the Prevention and Punishment of the Crime of Genocide (1948) as "...acts committed with intent to destroy, in whole or in part, a national, ethnical, racial or religious group..." Crimes against humanity include murder, extermination, torture, enslavement, persecution, deportation, imprisonment, rape and other inhumane acts when they are committed systematically or on a

\footnotetext{
${ }^{1}$ There is much less consensus over the place for crimes of aggression in this pantheon of crimes (Drew
} 2011). 
large scale by governments or other organized groups. ${ }^{2}$ War crimes overlap with crimes against humanity, when these crimes are committed during civil or international armed conflict. These include "grave breaches" of the Geneva Conventions, such as willful killing, or causing great suffering or serious injury to body or health, torture or inhumane treatment of civilians or prisoners of war. ${ }^{3}$

Almost every international judicial body since World War II has accepted most of these international crimes as punishable under international and national criminal law. A growing number of states have also incorporated major aspects of ICL into their domestic criminal code as well. Because of the nature of these international crimes, ICL norms are embedded in the norm complex at the intersection of international humanitarian law and international human rights law (Scheffer 2012).

Rooted in the notion that there should be universal, if minimal, standards of criminal justice applicable everywhere and to everyone, the norms surrounding criminal accountability have had to contend with other basic norms, including that of state sovereignty. Over the course of the past century, however, and especially since the Nuremburg and Tokyo trials of the 1940s, states and private actors alike have largely internalized the idea that individuals should be

\footnotetext{
${ }^{2}$ See the lists of such crimes as outlined in the Rome statute Article 7(1); The Statute of the International Criminal Tribunal for the former Yugoslavia (ICTY), Article 5; The Statute of the International Criminal Tribunal for Rwanda (ICTR), Article 3; The statute of the Special Court for Sierra Leone (SCSL), Article 2; The Law on the Establishment of the Extraordinary Chambers in the Courts of Cambodia (ECCC), Article 5; and the International Law Commission's Draft Code of Crimes against the Peace and Security of Mankind (1996), Article 18.

${ }^{3}$ Rome Statute, Article 8(2).
} 
held accountable internationally for the most heinous crimes. Since the end of the Cold War, norms of accountability for violations of international criminal law have given rise to ad hoc international or hybrid tribunals in the former Yugoslavia, Rwanda, Sierra Leone, Cambodia and Lebanon. The accountability norm has gained expression for the first time in history in a permanent and global institution, the International Criminal Court (ICC), which was created in 2002 when the Rome Statute entered into force.

How strong are the norms that support international criminal law accountability? Have they been strengthening or eroding over time, and how can we even judge such trends? Measuring norm strength is clearly complex. Conceptual attention has focused on state action and discourse. In this article, we put forward our argument of what we call the "diversity approach" to measuring norms. Key dimensions of diversity include cultural/regional diversity, actor diversity, and institutional diversity. We argue that diversity of support is also crucial for understanding normative robustness. On the one hand, narrow normative support suggests that norms are precarious. On the other hand, diversity among normative adherents helps to grant legitimacy to norms, increases their broad salience, and reduces the costs associated with defending them. We illustrate the usefulness of this approach by examining the norms of international criminal law.

We structure the remainder of this article as follows. First, we discuss common approaches in the literature to measuring the rise, contestation, and decline of international norms. As debates have stabilized over what constitutes evidence of norms' existence, we hold that robustness can best be gauged by the diversity of support. The diversity approach requires that we look for normative support and opposition beyond the official words and actions of a few states. Next, we provide some empirical examples of this approach in the case of 
international criminal law, such as the discourse on international criminal justice by international organizations, and public opinion on impunity. The evidence points to the existence of quite robust substantive norms, but highlights important challenges to norm applicability in the face of alternative contradictory norms. We conclude with a discussion of innovations for measurement that the case of international criminal law illustrates.

\section{Measuring Norm Robustness: A Diversity Approach}

Norms regulate interstate, state-to-person, and interpersonal relationships by defining unacceptable and/or obligatory behavior (proscriptions and prescriptions), solving problems of collective action, and "constituting" relationships (criminal/victim, state/rebel, etc.). Norms are widely understood as intersubjective standards and practices that create moral (and sometimes legal) claims on their addressees, concepts for which researchers need to develop observable proxies. Operationalizing and especially measuring norms has been "perhaps the most stubborn problem" in their scientific analysis (Raymond 1997, 206).

Most researchers investigate evidence of global norms in the justificatory discourse, policy positions, and actions taken at the "peak" of international relations, i.e., the traditional institutions of international governance. For example, UN Security Council resolutions embody the norm of collective security (Cortell and Davis 1996); the rise of the "global antipoverty norm" can be inferred from international declarations, resolutions, and policy statements (Fukuda-Parr and Hulme 2011); the norm of free trade can be inferred from GATT rules (Cortell and Davis 1996); human rights norms are reflected in the Universal Declaration of Human Rights (Risse, Ropp, and Sikkink 1999) or high-profile treaties such at the Convention on the Elimination of all Forms of Discrimination Against Women (Zwingel 2012). 
Relying on legal agreements and documents alone to describe international norms has long been recognized as problematic (Checkel 1997, 1999). Treaties do not inevitably signal deeper acceptance, elicit compliance, or alter practices (Wotipka and Ramirez 2008; Morrow 2014). Resolutions can be adopted for very different normative reasons; they can represent compromises rather than strong normative positions (Charnysh, Lloyd, and Simmons 2015). The "consensus" of the UNGA and the growing number of Security Council resolutions mentioning responsibility to protect $(\mathrm{R} 2 \mathrm{P})$ belie the significant application challenges to that principle (Zimmermann and Deitelhoff 2016). It is also possible to find weak international law where international norms are quite strong (Percy 2007). The point is this: it is important to look well beyond international resolutions and treaties for evidence of norm strength.

Rule-consistent behavior is also potential evidence of normative strength. Hyde (2011) views election monitoring as an international norm because it is widely practiced by states. Norms are said to degenerate if non-compliance becomes the rule rather than the exception (Panke and Petersohn 2012, 721). There are problems of course of relying too heavily on practice as evidence of norm robustness. Non-compliance often occurs even when rules and norms are widely accepted as legitimate (Hurd 2015); their status depends "upon a host of other factors, not the least of which is how the community assesses the violation and responses to it" (Kratochwil and Ruggie 1986, 767). The role of norm contestation is also contested for purposes of determining robustness, with some scholars arguing it is evidence of weakness (Kelley 2008; Cortell and Davis 2005, 9) and others claiming it can help to define and defend the validity of the norm. Some go further still and claim that even denial "suggests the entrapment power of an emerging norm" (Badescu and Weiss 2010, 369). 
The literature now seems to converge on a combination of approaches as the best guide to evaluating norm robustness, including (1) surveying the rules, (2) observing state behavior, and (3) noting the social response to violation (Legro 1997, 33-34; Panke and Petersohn 2012; McKeown 2009). ${ }^{4}$ Clearly, it is important to bring a broad range of evidence to bear on the measurement of norm strength (Goertz and Diehl 1992; Raymond 1997). But we agree with Price $(2006,260)$, who concludes that "no quantitative rule is available to determine definitively the threshold of what amount of state practice among how many states constitutes a settled international norm." Yet in so doing, we see no reason to restrict this conclusion to states. Modern international relations are influenced by constellations of non-state actors whose views and actions may be relevant for assessing the robustness of a "global" norm, inasmuch as they are expected to operate within the constraints of international criminal law as well. These norms are increasingly "legalized" by statutes, courts, and legal actors at the international, regional and domestic levels. A true picture of norm robustness should take these sources of support and contestation into account, as well as the official views of states.

If the last few years have taught us anything, it is that elite views often do not capture widely held values and opinions. In this section, we claim that norms are more robust when they enjoy diverse support. Support

\footnotetext{
${ }^{4}$ Legro (1997) argues that norm strength is indicated by how well actors understand, publicly subscribe to, and respond to the violation of behavioral expectations. For Panke and Petersohn, it is active unsanctioned non-compliance with norms that triggers norm erosion $(2012,726)$; others look for explicit disapproval in a "range of social practices, which discursively express disapproval of norms" (Wiener 2014, 1). Gelpi (1997) theorizes that prior settlements constitute the normative environment; when others respond to violated settlements, states suffer reputational costs.
} 
for a norm is more diverse when it comes from (1) a range of state actors from different normative traditions, cultural perspectives and material interests; (2) both official state actors and international organizations; (3) a range of non-state actors; and (4) a range of institutions at international, regional and domestic levels. Norms are strongest when supported by a broad range of actors with varying motivations, interests, power resources, and normative status. Scholars have suggested that we look at regional responses to foreign ideas for evidence of normative acceptance (Acharya 2004, 253; Kelley 2009), arguing that local acceptance increases confidence that international norms have some degree of local relevance. Our claim is somewhat different. It is not just local acceptance that matters; the diversity of those accepting the norm matters as well.

Why does diverse support for a set of norms make them more robust? First, diverse support boosts the global legitimacy of normative claims. Legitimate norms are those around which consensus has formed regarding the norms' representation of what is right, rather than what is merely in an actor's interest. Norms that are broadly viewed as legitimate are more likely to be complied with at lower cost. They are not easily criticized as merely a reflection of some actors' special interest or narrowly defined cultural values. In this sense, diverse support is likely to contribute to norm robustness.

Diverse support is also important to robust norms because of what one might call a portfolio diversification effect. Portfolio theory suggests that returns to investment can be best maintained when the returns to assets in an investment portfolio are not highly correlated (Markowitz 1968). Suppose that states are willing to support international norms, but only when it is not too costly to do so. When a specific norm begins to stabilize, we can think of its supporters - for example, treaty ratifiers - as a set of asset holders whose interests can change 
over time in response to various kinds of (un)anticipated shocks. If the same shock affects all norm supporters in the same way, the norm may be highly desirable for all states parties under some circumstances, but may well lose nearly all support and collapse under others. If all state supporters of ICL were contiguous countries susceptible to violent rebel movements, they might all abandon a norm banning war crimes under the (possibly contagious) threat of rebellion. Similar to a diverse investment portfolio that is stable when risks balance, norms may enjoy more stable "returns" and hence support when members face diverse costs under varying conditions. This is most likely when the norm supporters themselves are diverse.

Diversity supports norms by enhancing regime credibility. Diverse support for a norm suggests that actors with a range of capacities and varying interests may be willing to take steps necessary to enforce the norms sit contains. Enforcement would be less credible were members all equally unable to credibly enforce norms when necessary. Institutional development across diverse governance levels also contributes to more robust norms. Cortell and Davis $(2005,8)$ contend that "focus on the state's [domestic] policy agenda provides a more objective and replicable measure" than international actions alone. But not only are domestic commitments an indicator of norm internalization; we argue they can be essential to a norm's global robustness. If an institution at one level fails, alternative institutions may be positioned to support the norm in question. The ICC is designed with this principle in mind: it is built on the complementarity of international prosecution to domestic (and perhaps regional) efforts to hold ILC violators criminally accountable.

Finally, norms are more robust when non-state actors accept, rather than resist them. "Diversity of support" spans the official (governmental)/civil (non-governmental) spectrum. This is crucial because norms are not the special arena of states alone. Especially, but not only in 
democracies, people can influence their governments to take normatively appropriate actions. Importantly, non-state actors acting as individuals are bound by the norms of ICL as well. Their attitudes and actions directly impact norm strength. This is especially true of non-state groups who might be expected to resist; i.e., rebel and other resistance groups for whom adherence could potentially undercut their military advantage.

Diverse support itself can be genuine or it can be strategic. Clearly, the norms underlying the international criminal law regime rest on fundamental, commonly held values that hold that mass killings of innocent civilians and similar atrocities, whether in war or during peacetime, are grossly malem in se. But it is also possible that fundamental ICL norms are robust because violating them has meaningful consequences. Purposeful norm deniers are likely to encounter a range of politically unpleasant allegations, from criticism to censure to social exclusion to economic sanctions to prosecution. ICL norms are reiterated and enacted, partly because almost nobody wants to be seen as in favor of genocide. Norm robustness is almost certainly related to the inherent nature of and abhorrence surrounding atrocity that ICL norms are designed to counter. These underlying values contribute to broad and diverse support, and consequently to norm robustness, even when norms are violated in specific circumstances.

We think this diversity approach will be useful in the study of norms - as a theoretical basis for norm robustness and as a measurement strategy. Diversity itself of course stems from widely shared human values that social pressures and entrepreneurial advocacy enforce. But since values are difficult to observe and strategies of norm entrepreneurs may or may not be competently pursued, we argue that empirical researchers should seriously study the diversity of normative support that the above-described dimensions express or infer.

The diversity approach to understanding norm robustness will be useful to research in many 
situations, although the weights on each constituency in the "diversity set" might differ across issue areas. This may depend on actors' stakes, interests, power, and mobilization capacity. For example, norms about the circumstances under which it is appropriate to declare war might openly privilege the actions and rhetoric of state actors, since it rests on an even more fundamental norm that defines states as the creators and active users of such norms. In contrast, norms that involve global justice - such as ICL norms - are especially amenable to the diversity approach, as accountability for international crimes involves individual victims and perpetrators. In this sense, our diversity approach will be applicable particularly to understanding and measuring the class of norms that apply to more than just one concentrated set of norm creators and addressees.

\section{Measuring ICL Norm Robustness: Multiple Levels of Discourse}

If diversity among supporters is a source of strength for international norms, then the next issue concerns how we might explore this relationship empirically. We demonstrate the diversity-based measurement strategy in the case of ICL norms. First, we examine diversity among states supporters, examining their discourse and actions. Second, we look at support among a range of non-state actors. We break with tradition in this area by looking for normative support among unorganized public opinion as well as among organized groups that might be expected to resist norms of ICL. Finally, we look for varieties of institutionalization: the development of laws and courts - national, regional and international - that suggest the norms of ICL are robust.

Diversity among State Actors 
One of the most traditional areas to document the existence of norms is within debates that occur within the framework of the United Nations. UN General Assembly (UNGA) and Security Council debates, reports, and resolutions provide evidence the emergence of an international norm requiring states to protect populations from genocide, war crimes, ethnic cleansing, and crimes against humanity (Matthews 2008). The UNGA may be primarily a forum for posturing, but it also provides clues as to the kinds of issues states consider to be important (or think they will be socially rewarded for discussing, another indicator of normative salience). In this forum, there has been growing attention to some of the central ICL norms. Figure 1 charts attention to two major international crimes in UNGA resolutions, war crimes and crimes against humanity. It suggests a thickening rhetoric surrounding international criminal law in the world's only general global forum.

[Figure 1 about here]

The United Nations Security Council (UNSC) is another political actor whose discourse provides clues about norm robustness. The UNSC used its powers twice to set up international ad hoc courts to address ICL violations in the Former Yugoslavia ${ }^{5}$ and Rwanda. The former is noteworthy because, given Serbia's close relationship with Russia, it would have been quite possible for the ICTY to have been vetoed; instead it was supported by a unanimous vote. ${ }^{6}$ Since 2002, UNSC resolutions can also refer a situation to the ICC. Among the "situations" in the Court's docket as of August 2018, Sudan and Libya were referred by the UNSC. The first UNSC Resolution 1593 in

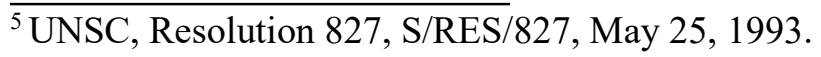

${ }^{6}$ This is not to say that the creation of the ICTY was not without political obstacles at the United Nations. UNGA for example kept tight budgetary control, almost making the ICTY impossible (Bass 2002, 221).
} 
2005 required all states to cooperate with the ICC on the situation in Sudan. ${ }^{7}$ Two permanent members, the United States and China, abstained in this case. The second UNSC Resolution 1970 in 2011 concerned Libya. ${ }^{8}$ The fact that two permanent members (USA and China) abstained from voting on the Sudan case but voted in favor of ICC referral in Libya's case suggests some broadening of state support. Moreover, the UNSC has used its power to sanction ICL violations by imposing sanctions on various rebel leaders - some of them in response to atrocities committed by rebel groups (Charron 2011).

Of course, the Security Council is a political institution, and the decision to support or oppose a referral depends on much else besides normative enthusiasm (Schroeder and Tiemessen 2014). It is difficult to imagine, for example, that the Syrian situation will be referred to the ICC, since both Russia and China vetoed a draft resolution to that effect in 2014. Given the brutality of this particular conflict, the fact that only 58 - less than a third of the 193 UN members and less than half of the approximately 120 States Parties to the ICC itself - states co- sponsored the resolution referring the Syrian situation to the ICC suggests to some "an advance for the principle of impunity for war crimes. ${ }^{.9}$ Moreover, the coalition for referral was noticeably homogeneous, further hinting at its weakening. Only six sponsors were from Africa (Botswana, Cape Verde, Cote d'Ivoire, Ghana and Seychelles), two were from northern Africa (Libya and Tunisia); five from Latin America (Chile, Costa Rica, Panama, Paraguay and Uruguay); two from Asia (Japan and Republic of Korea); and three from the Pacific (Cook

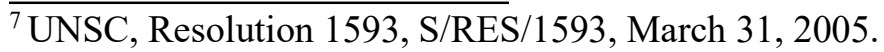

${ }^{8}$ UNSC, Resolution 1970, S/Res/1970, February 26, 2011.

${ }^{9}$ The Guardian, 22 May 2014. Available at: https://www.theguardian.com/world/2014/may/22/russiachina-veto-un-draft-resolution-refer-syria-international-criminal-court
} 
Islands, Marshall Islands and Samoa). The balance - or nearly 70 percent of the sponsors for Syrian referral - were European. ${ }^{10}$ Some states on the Security Council - notably Jordan, Chile, and Rwanda - called for members to refrain from use of the veto in cases of crimes against humanity, genocide, and large scale human rights violations. Others - Chad and Argentina for example - ambiguously refused to support the draft resolution but claimed to support referral. ${ }^{11}$ Overall, the clear impression is that primarily European voices are fueling demands for robust norms against ICL impunity. Europeans have strong moral authority and provide generous material support to uphold the ICL norms, but the norm would be more robust were support solid among major powers and more distributed across cultures and regions.

\section{Non-state Actors}

Norm robustness is not merely a matter of state position-taking. Civil society matters as well. This is most clearly the case in states that are governed democratically, and in which governments occasionally listen and consult with a broad range of civilian entities. Norms are strengthened to the extent that civil society takes them seriously. Without such support, governments could much more conveniently change their positions to reflect their immediate interests. When public support for a set of norms is present, official normative pivots based

\footnotetext{
${ }^{10}$ The complete list of sponsors for Syrian referrals are available at https://www.hrw.org/news/2014/05/19/public-statement-58-states-call-un-security-council-adopt-frenchresolution.

${ }^{11}$ See summary of Rwanda's statement at https://www.un.org/press/en/2014/sc11407.doc.htm.
} 
purely on convenience are more difficult to make. In this section, we examine the evidence on ICL discourse from the "bottom up."

Public opinion. State positions are not the final word on international criminal justice norms. Peoples' opinions matter particularly in the field of ICL because civilians are often the victims of international crimes, and their views sometimes shape the context in which political leaders operate. Moreover, the general population influences the successful implementation of ICL. Ordinary citizens are crucial in the collection of evidence, and must eventually cope with the consequences of pursuing justice (or not). Public opinion is therefore relevant for the robustness of ICL norms. ${ }^{12}$ Public opinion may not be strictly "intersubjective" in the way this term is used in academic literature, but we believe this view seriously underestimates the extent to which individual opinions are socially influenced by neighbors, surroundings, and shared experiences. To ignore public opinion when thinking through norm robustness is to ignore the very agents on whose behalf these norms are supposed to operate. When publics support international criminal law norms, this help to make them more robust.

Though popular knowledge about international criminal law is admittedly limited, evidence points to the existence of public support for the core norms of international criminal law, but also to applicatory contestation exists. In this section, we examine public support for the ICC. Supporting the ICC is not exactly the same as supporting norms of international criminal law: many who would support ICL norms oppose the ICC taking the lead in prosecutions. Nevertheless, nearly

\footnotetext{
$\overline{{ }^{12}}$ Take the example of recent referendum in Colombia where voters rejected the negotiated deals with FARC. One of the primary reasons cited is people's anger that justice was not done. See "Colombia's Peace Deal with the FARC Failed" New York Times, October 3, 2016.
} 
everyone who supports ICC prosecution also likely strongly supports international criminal law norms. Even in jurisdictions where states remain aloof from formal global institutions, there is a strong, if vague, sense of support for ICL norms. $60 \%$ of Americans, for example, agreed that "it is important for the United States to participate in international organizations that support human rights and that hold individuals accountable for mass atrocities." 13 The majority of Americans robustly support ICL norms and are even favorably disposed toward an international court that their government has declined to join. ${ }^{14}$

A series of surveys have gauged public opinion regarding justice in conflict-ridden places experiencing ICL violations. Interestingly, many surveys find that people know little about institutions such as the ICC, even though they tend to have a favorable opinion about it the organization. ${ }^{15}$ An early Gallup poll (2005) in sixty-seven countries found that a minority profess to not know much of anything about the ICC, but also that about forty-five percent of the surveyed population was supportive of the institution. Only thirteen percent had a negative opinion. $^{16}$

What does such ignorant position-taking

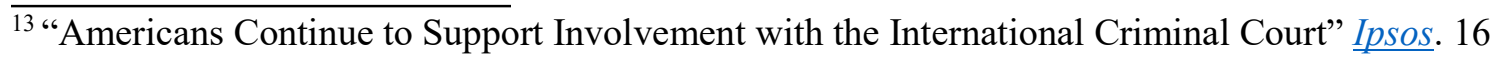
December 2014. The proportion grows to 70\% among those who claim they know something about the ICC itself.

${ }^{14}$ We note two references in particular: Chicago Council on Global Affairs (September 2012, June/July 2006), World Public Opinion \& Knowledge Networks (May 2006), and Foreign Policy Association/Zogby International (September 2004).

${ }^{15}$ According to a range of surveys, some $10-70 \%$ of respondents were aware of the International Criminal Court (Crabtree and Tortora 2009, Economist 2012, Vinck et al. 2008, Vinck and Pham 2010, Pham et al. 
2009, Pham et al. 2005, Pham et al. 2007).

${ }^{16}$ Voice of the People, 2005 (ICPSR 04636), ICPSR, http://dx.doi.org/10.3886/ ICPSR04636.v1. 
mean? Since the Court had issued no arrest warrants at the time of the survey, Erik Voeten (2013) concludes that such relatively high levels of trust may have come from "general preferences" and "values" for which the ICC stands. Chaudoin and Chapman (2016) also find in their survey experiments in Kazakhstan that people approve the work of ICC generally, although such support can erode in local circumstances. ${ }^{17}$ These studies suggest that people care about justice in the context of war crimes, crimes against humanity, and other atrocities, evidence that ICL norms do enjoy support among publics who have suffered violations. Although the contestation over applicability exists even among members of the public - about how to apply justice, with what means and in what ways - the core norm of anti-impunity and the sense that there is no free pass for atrocities appears to be strong.

Kenyan public opinion is especially interesting, given the systematic effort of the government to claim immunity from prosecution for international crimes. As discussed above, immunity for heads of state is one of the more controversial norms of ICL. But despite the government's campaign against the ICC, 61 percent of Kenyans agreed or strongly agreed that "ICC- led prosecution is important in fighting impunity"; 86 percent agreed or strongly agreed that "President Kenyatta made the right decision in honoring the ICC summons"; and 55 percent of the population disagreed or strongly disagreed that "Kenya should withdraw from the ICC" (Lekalake and Buchanan-Clarke 2015, 6). Opinion in the country is divided along lines of ethnic support and opposition to Kenyatta - as many as $87 \%$ of the opposition Luo support the ICC, while only 34 to 44 percent of his Kikuyu and Kalenjin supporters do (Lekalake and BuchananClarke 2015, 7). Nationwide, however, there is strong support for holding government officials and even

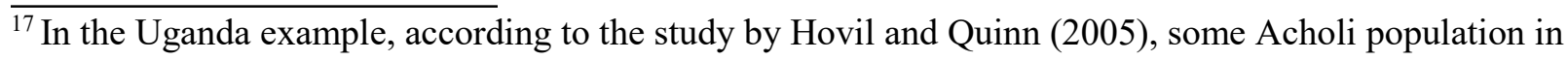
Uganda preferred traditional local justice system, mato oput, over international justice system. 
heads of state accountable for ICL violations. Among conflict-affected areas in Kenya, only 34 percent of people agreed with the statement that the ICC is biased toward Africa, indicating some support for global justice (Alleblas et al. 2017).

In short, public opinion - though limited - is surprisingly supportive of international criminal law application in some local situations. How people perceive, demand, and support international criminal justice is relevant to whether the norm is taking root or becoming widespread.

Organized Civil Society. Next, we turn to the discourse of organized non-state actors. Human rights groups contribute significantly to norm robustness in international criminal responsibility (Glasius 2006). One example is the Coalition for the International Criminal Court, a non-governmental organization that advocated legal/technical assistance in implementing international justice (Schroeder and Tiemessen 2014). Sometimes they promote international justice norms with important innovations on the ground. The implementation of mobile gender courts in the Democratic Republic of Congo around the decision of Thomas Lubanga is one such example (Lake 2014).

As monitors and information-providers, human rights groups have strengthened ICL norms by proactively gathering evidence and submitting petitions to the International Criminal Court. ${ }^{18}$ Importantly, human rights groups contribute to norm robustness when they critique misplaced or inappropriate enforcement efforts. For example, some local human rights groups criticized ICC operations in Uganda, and suggested ways it might better perform under local conditions (Hovil 2011). Such groups contribute to the general discourse surrounding

\footnotetext{
$\overline{{ }^{18} \text { See Human Rights First (2004). }}$
} 
international criminal law; they also clearly contribute to mobilization and institutional effectiveness, which we discuss in greater detail below.

Rebel Groups. Most discussion of norm discourse concentrates on their advocates. It is crucially important, however, to consider the discourse of those who might be most expected to push back against the norms in question. Armed rebel groups - military organizations that fight against national governments in civil conflicts - do not directly participate in formal norm negotiating processes, yet their stance is critical to the robustness of ICL norms. ${ }^{19}$

Interestingly, rebel groups' understanding of international criminal responsibility and protection norms has changed over time. We have examined the Directory of Armed Non-State Actor Humanitarian Commitments, ${ }^{20}$ the archive constructed by the Geneva Call, a nongovernmental humanitarian organization. The archive features primary and secondary documents that reflect rebel groups' expressive commitments related to international humanitarian law ${ }^{21}$ the body of international law that overlaps with ICL relating to war crimes and crimes against

\footnotetext{
${ }^{19}$ The Rome Statute directly addresses non-state armed groups and hold them accountable. Schabas 2012. ${ }^{20}$ The database is available at http://theirwords.org/.

${ }^{21}$ For primary sources, ICRC archive (non-state armed groups often deposited commitments to the ICRC and the ICRC has amassed its collection of non-state armed groups' internal documents as well as expressive commitments to international humanitarian law), Geneva Call's own archive as the organization negotiated the Deeds of Conduct in about 35 countries (consider approximately 40 countries are in civil wars in any given year), soft law documents that state rebel groups' commitment to stop the use of landmines, or to stop the use of child soldiers or sexual violence. The secondary sources cover scholarly articles or works published by think tanks related on this topic.
} 
humanity. About 60 out of a total of approximately 300 rebel groups between 1980 and 2015 make such a commitment, which attests to the breath of the norm's expression. ${ }^{22}$

The language used to articulate norms of rebellion suggests that ICL norms have at least some resonance even among rebel groups. Figure 2 plots two categories of rebel words: 1) words related to international humanitarian norms and 2) words related to "political demands." Over time, in terms of the probability of a particular topic appearing in a document, we see that humanitarian norm-related words (e.g. "right" "children" "people" "human") are increasing, while words related to rebels' political demands (e.g. "nation" "govern") are decreasing. The graph shows some recognitions among rebel groups of norms related to human rights and humanitarian law, although these topics are not explicitly related to international crimes. More directly related to issues of international criminal law, some rebel groups develop their internal codes of discipline to reign in the behavior of their soldiers in order to prevent war crimes and crimes against humanity. At the very least, these instances signify an awareness of international standards, as well as the recognition of the need for mechanisms that address criminal law within rebel ranks. Recent research also shows that rebel groups may even be willing in some cases to be bound by international law (Jo 2015).

[Figure 2 about here]

Thus far, we have argued that states are not the only actors whose words, acts, and commitments constitute norm robustness. Civil society contributes to norm robustness through its advocacy. States register their support and reservations not only when they ratify agreements,

\footnotetext{
${ }^{22}$ This claim is based on the comparison of rebel group list in the Uppsala civil conflict dataset to the list within the Geneva Call's archive.
} 
but also in debates in the United Nations General Assembly. Norm robustness can also be gauged when rebel groups stake positions relating to humane forms of rebellion. However, none of this suggests normative convergence over where and how international criminal law should be enforced. In the next section, we concentrate on evidence of ICL robustness as reflected in various levels of institutionalization.

\section{Measuring ICL Norm Robustness: Institutionalization across and within States}

Institutionalization is another traditional way to measure norm strength. Institutions are fairly stable structures that represent long-term investments in articulating, diffusing, and enforcing specific norms and rules to support them. International criminal law institutions have developed internationally and proliferated domestically, especially since the 1990s. This is an important dimension of norm robustness, because the commitment to develop and sustain international institutions represents real resources backing the discourse and opinion we have explored above. Moreover, institutions can help sustain normative commitments. Their diffusion

- internationally, regionally and nationally - creates structural redundancy that reflects a commitment to enforce ICL norms and reduce impunity. We begin with international developments and then turn to institutional diffusion in domestic law.

International institutions: regional and international courts

Over the course of the 1990s, there has been fairly broad participation in the development of norms and institutions for international criminal law enforcement. In contrast to the narrowly 
conceived justice of the allies post-World War II, construction of the international criminal regime of the 1990s was an international project. The United Nations was at the core of this move, and although many motives may underlie developments, critical coalitions of the major states supported norm development. Adoption of Security Council Resolution 827, which created the International Criminal Tribunal for the Former Yugoslavia (ICTY), was unanimous and passed in 1993 without abstention - a notable achievement given Russia's alliance with Serbia and China's tendency to vote for non-interference. Security Council Resolution 955, which established the International Criminal Tribunal for Rwanda (ICTR) in 1994, garnered 13 positive votes, one negative vote (from Rwanda, who opposed the courts location in Kigali and its inability to impose the death penalty, among other issues). Significantly, China abstained, justifying its vote with the view that genocide is an internal matter (Schabas 2006, 29).

In 2000, the Security Council unanimously passed Resolution 1315 without abstention, calling on the Secretary General to begin negotiations with Sierra Leone for a Special (hybrid) Court to deal with crimes against humanity, war crimes, and other serious violations of international humanitarian law. After a 1997 request by the government of Cambodia for assistance in bringing violators of international criminal law to justice for crimes "Committed During the Period of Democratic Kampuchea," the United Nations General Assembly in 2003 adopted (without vote) a draft of The Extraordinary Chambers in the Courts of Cambodia. Security Council unanimity (with the important exception of China and Rwanda) signaled the strengthening norms in this area. It is common to assert that the Security Council acted in these cases out of a reluctance to commit troops to intervene militarily, rather than out of any sense of an obligation to punish international crimes (Shraga 2011,31). Nevertheless, the above examples show that the United Nations did act authoritatively in these cases, with but one negative vote 
and one abstention. The norm of international criminal accountability was gathering steam, with broader support than had been the case in previous decades.

Moreover, there is evidence that this machinery has in fact enforced the law in a range of cases. Figure 3 reports the number of persons charged and the prosecution rate for each of three kinds of international crimes for five international/hybrid tribunals set up since the early 1990s: Yugoslavia, Rwanda, Sierra Leone, Cambodia and the ICC. In both ICTY and the ICTR cases, hundreds of charges were brought for war crimes, crimes against humanity, and in the case of Rwanda, genocide. The SCSL has had the highest conviction rates overall - 54 percent conviction rate for war crimes, and 60 percent for crimes against humanity. The ICTR obtained convictions in 33 percent of all genocide cases, and in 40.5 percent of cases involving crime against humanity. About a quarter of all charges of war crimes and crimes against humanity ended in convictions before the ICTY. The laggard would seem to be the ICC, which has convicted only two persons as of December 2015. ${ }^{23}$ On 17 March 2006, Thomas Lubanga Dyilo became the first person to be convicted by the ICC for "conscripting and enlisting children under the age of fifteen years and using them to participate actively in hostilities," a war crime under international criminal law. Germain Katanga was convicted on March 7, 2014, on five counts of war crimes and crimes against humanity, as an accessory in the February 2003 massacre in the village of Bogoro in the DRC.

[Figure 3 about here]

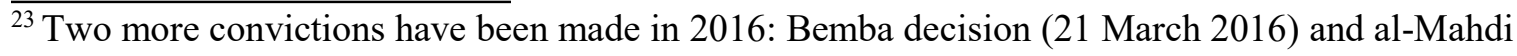
decision (24 March 2016).
} 
Are these rates "good"? There are always difficulties when it comes to interpreting the appropriateness of conviction rates. High rates can certainly reflect low standards of due process. Sham trials are a relatively surefire way to get the judicial decision that is politically desired. Furthermore, conviction rates depend not only on success, but on the baseline caseload as well. Another way to obtain high conviction rates is to proceed with very few cases, and only those that are nearly water- tight. As such, we counsel caution in interpreting these rates. Nevertheless, they are comparable to those for "ordinary crimes" in national courts. According to the United States Bureau of Justice Statistics (2016), among felony defendants whose cases were adjudicated within the one-year tracking period ( 89 percent of all cases), 68 percent were convicted.

The move to establish a global ICC gained momentum during the 1990s. The process took place outside of the Security Council, and was thereby able to circumvent obvious resistance by three out of five of the permanent members. Trinidad first put forward the idea of an international court to handle criminal issues (drug trafficking was a particular concern), but the center of gravity of support was heavily European. The strongest supporting countries formed a "Like-Minded Group" to concentrate effort and strengthen the outcome. Almost half of this group - 26 out of 56 countries - were European states, but it also included 12 African countries and a few influential Latin American states, such as Argentina. ${ }^{24}$ The Philippines, Singapore, and the Republic of Korea were the only Asian states among this likeminded group.

\footnotetext{
${ }^{24}$ For a complete list of the like-minded group see The Rome Treaty Conference Monitory, The International Criminal Court Monitor, NGO Coalition for an International Criminal Court, Issue 15, p. 1, July 3, 1998, Provided to authors by Coalition for an International Criminal Court.
} 
The Like-Minded States were among the most committed to the norms of international criminal accountability, and they were also very likely to ratify the ICC statutes (Simmons and Danner 2010). However, the breadth of support for these norms is also apparent in the regional diversity of state ratifications (Figure 4). The figure shows that the ICC has gleaned support from states in at least three regions of the world - Europe, Africa, and Latin America.

[Figure 4 about here]

Figure 4 also suggests that the ICC has probably attracted all of the adherents that it is likely to attract; the states that have not joined are either norm agnostic or norm resistant. Clearly, some of the largest and most powerful states in the world are not on board: China, India, Russia, and the United States. These countries did not fully support the Rome Statute for various reasons: China objected to the ICC's jurisdiction, prosecutorial power, and coverage of crimes (Jia 2006); India did not sign the Statute due to concerns about the Court's reach into internal affairs and concern over the power of the United Nations Security Council over the Court ${ }^{25}$; Russia signed but has not ratified the Statute, and while this is not likely to change, basic support for international justice norms has been expressed at least diplomatically (Kaye 2013, 12-13). The United States signed but did not ratify primarily out of security concerns for American troops (Sewall and Kaysen 2000). It is notable, however, that these detractors have at times made accommodating moves toward the Court or faced unintended consequences. China has become more accommodating to the role of the Court over time (Hafetz 2016, Jia 2006), and the U.S. has occasionally cooperated with the Court (Bosco 2014). In India,

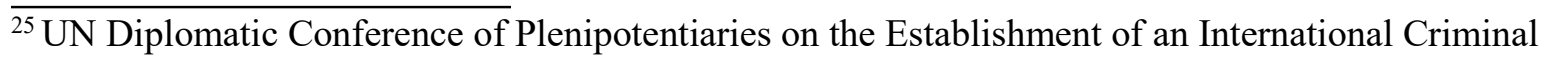
Court (Volume I, II and III). A/CONF. 183/13. United Nations. Official Records, Rome, 15 June-17 July 1998. 
the Rome Statutes "provided the languages to challenge impunity" among civil society actors in the wake of the Gujarat violence in 2002 (Ramanathan 2014).

A broad range of states has supported the institutionalization of criminal law institutions with real resources. In fact, about $80 \%$ of all States Parties to the ICC have paid in full, with notable exceptions in Africa (Congo, Malawi, Tanzania, who have each lost their vote due to non-payment) and Latin America (where the most significant arrears are owed by Brazil, Venezuela, and Argentina). ${ }^{26}$ On the one hand, most states - even some that have been investigated - have come close to fulfilling their financial obligations to the Court. ${ }^{27}$ For instance, for all its controversies relating to the Court, Kenya appears to have paid in full. On the other hand, four states have formally attempted to withdraw from the ICC: Burundi, Gambia, South Africa, and more recently, the Philippines. These defections are obviously highly concerning especially since Burundi is poised for widespread violence, and South Africa and the Philippines were among the original group of Like-Minded supporters. The counter-contestation was manifest when Gambia reversed its decision within a month of announcement, and South Africa revoked its withdrawal decision after its high court ruled such withdrawal unconstitutional. Among the four cases mentioned above, only Burundi completed the withdrawal process in 2017 . The attempt to withdraw and subsequently to reverse such decisions

\footnotetext{
${ }^{26}$ See more in Van Leeuwen 2015.

${ }^{27}$ For a list of investigations see ICC 2016 "Situations under Investigation" International Criminal Court. Retrieved 15 November 2016. For assessments, payments and arrears, see Report of the Committee on Budget and Finance on the work of its twenty-fourth session ICC-ASP/14/5. 18 June 2015. Annex I: Status of contributions as at 20 April 2015. Posted at: https://www.icccpi.int/iccdocs/asp docs/ASP14/ICC-ASP-14-5-ENG.pdf.
} 
hint at some contestation over Court jurisdiction, although the core impunity norm itself does not appear to have been undermined. ${ }^{28}$

\section{Domestic Institutionalization}

Norms are more robust when they are supported by institutions at different governance levels. This is especially so for norms of international criminal law that lacks enforcement capacity on the international level; even with the creation of regional courts and the ICC, it is clear that these institutions have not been able to handle every potential case that might come to them. Changes in domestic crime statutes enhance monitoring and enforcement capabilities, although in less well-functioning states, this might take effect slowly (Jo and Simmons 2016). The existence of the ICC creates incentives for states to strengthen their own legal capacities to try and convict individuals of international crimes (Dunoff and Trachtman 1999; Burke-White 2008), likely stimulating substantial change in national law to reflect international norms. A recent ICC report to the United Nations notes several national legal reforms that have been implemented after the launch of preliminary examinations, including reforms in Guinea, Colombia, and Georgia (ICC 2011). Sarah Nouwen (2013) also documents how ICC investigations catalyzed legal reforms in the DRC and Sudan. Uganda's ICC implementing legislation was passed only recently, in 2010, but it empowers the Ugandan High Court to prosecute international crimes (Nouwen and Werner 2011). The DRC passed a domestic law incorporating the elements of the Rome Statutes as recently as January 2016, although it is too early to tell how these domestic laws will be

\footnotetext{
$\overline{{ }^{28} \text { See Bower in this Special issue }}$.
} 
Implemented. Nevertheless, it is important to note that national courts have contributed to a broader system-wide expectation that impunity is no longer quietly tolerated (Sikkink 2011). ${ }^{29}$

[Figure 5 about here]

Figure 5 shows the diffusion of ICL-consistent national crime statutes over time, and by region. We coded the national criminal legislation information using the "National Implementing Legislation Database (NILD)" in the ICC Legal Tools database. The increasing trend for every region indicates that it was not just the European continent that went through the domestic crime statute reforms, but also other regions of the world.

In sum, the foregoing evidence demonstrates that diverse institutions bolster norms, especially when violations have been alleged. We do not claim that these institutions operate perfectly or fairly, but we do think enforcement mechanisms at the international, regional and national level constitute evidence that ICL norms are broadly accepted around the world.

\section{Measuring ICL Norm Robustness: Contestations}

In this last section, we consider contestations - challenges to the norm, and the extent and breadth of those challenges. According to our diversity approach to measuring norm robustness, if challenges to both core norms and their application come from a diverse set of actors, then we would conclude that the norm is fragile. If the challenge is limited in scope and

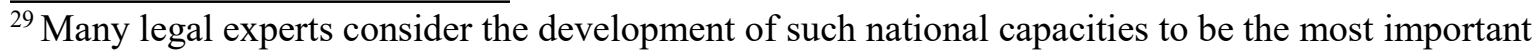
legacy of the ICC. See Slaughter and Burke-White (2006, 339-341) and Burke-White (2008).
} 
the attack comes from a small set of norm addressees, with supporters vigorously defending ICL norms, then we could say that the norm remains robust.

Whether norms can weather resistance is a crucial test of their robustness. Norms that matter the most often provoke contestation of some form or another. Although contestation could indicate norm demise, it could also potentially strengthen norms by drawing attention to them, attracting new defenders, and rearticulating the original values that gave rise to the norm in the first place. We stress, however, that this is a possibility; there is no reason to think that contestation always anneals normative commitments. Consistent with the framing paper's conjecture, we adopt the view that norms are robust to the extent that norms' validity is not challenged, even though applicability contestation exists.

How has the norm of individual criminal responsibility weathered opposition? One of the first concerted efforts to undermine the ability of the international community to apply international criminal law to all persons came shortly after $9 / 11$. The tragedy provided the opportunity for the Bush Administration in the U.S. to articulate a set of counter-norms that would exempt American citizens from ICL enforcement by the ICC. Unwilling to risk the possible surrender of American citizens to the Court's jurisdiction, the US engaged in a worldwide "Article 98" campaign, asking countries to sign bilateral agreements with the United States not to surrender Americans to the Court. Judith Kelley (2007) studied the incidence of nonsurrender agreements and found that countries with strong rule of law that had ratified the Rome Statutes tended not sign Art 98 agreements with the United States; while some countries with low rule of law signed the immunity agreements even after ratification. Her study implies that the norm of individual criminal responsibility was defended by states that take law seriously, even at the cost of angering the United States. The United States soon came to view ICL accountability as in its interest 
when it pushed to refer the situations of Sudan and Libya to the ICC in the UN Security Council (Bosco 2014; Heyder 2006).$^{30}$ This suggests that US actions should not be interpreted as an assault on ICL, but rather as an effort to enforce its norms through institutions it can control. The EU reacted to the US strategy with a combination of opposition and realism. Europe issued a set of guidelines for states to follow that were intended to contain the damage that US BIAs could wreak on the norm of universality (European Council 2002). The EU was able to prevent its own members from signing such agreements, but was not able to prevent states on its periphery or a significant number of African states from doing so.

The United States is hardly the only state to attempt an end-run around ICC jurisdiction. The Kenyan Government also made a concerted effort to discredit the ICC when the sitting president was accused of inciting violence that potentially amounted to crimes against humanity (Nichols 2015). In the midst of its investigation, Uhuru Kenyatta was elected as a president in 2013. After much controversy, the charges were dropped in 2014, mainly because the Kenyan government failed to hand over crucial evidence to the ICC (ICC 2014b). The Trial Chamber found that "cumulatively, the approach of the Kenyan Government...falls short of the standard of good faith cooperation" and "that this failure has reached the threshold of non-compliance required under the Rome Statute" (ICC 2014a). The Kenyan government actions ranged from undermining the Waki Commission (Commission of Inquiry into the Post-Election Violence), to mobilizing international support via shuttle diplomacy, to buying time in court or intimidating witnesses (Mueller 2014).

What does this case say about norm robustness? Scholars and observers note that the Kenyan public supported the ICC actions in Kenya. The investigation galvanized judicial reforms in Kenya. The Kenyan government's effort to discredit the ICC

\footnotetext{
$\overline{{ }^{30}}$ The US abstained from the Darfur case.
} 
certainly challenged its jurisdiction, but other indicators suggest that ICL norms were successfully spread and generated political actions that contributed to their eventual entrenchment. Perhaps surprisingly, Kenya is now one of the few African member states that, as of April 2015, has paid its dues in full to the ICC..$^{31}$

The African Union (AU) has fiercely criticized the Court's operation, complaining generally that the Court to date has prosecuted Africans exclusively. ${ }^{32}$ The AU has vociferously opposed the prosecution of sitting presidents from the continent, in January 2011 demanding that Kenya's Ocampo 6 be tried in domestic courts (Mueller 2014). The AU's staunch support for alBashir, Sudan's sitting president who was indicted by the ICC in 2009, is another challenge to the ICC. When Bashir attended an AU summit in Johannesburg in 2015, the government of South Africa refused to arrest him, claiming he had head of state immunity. South Africa's High Court made an interim order that al-Bashir could not leave South Africa until it "reached its decision on enforcing the ICC arrest warrant. ${ }^{" 33}$ The AU, however, did not back up this effort. In June 2015, Bashir escaped capture for the third time. The AU continues to undermine the ICC by attempting to pass resolutions that its members pull out en masse (Mueller 2014). These norm- defying actions have, however, generated important reactions from norm-defenders: 164 local and international human rights groups in Africa have publicly opposed the AU's actions in 2009 and

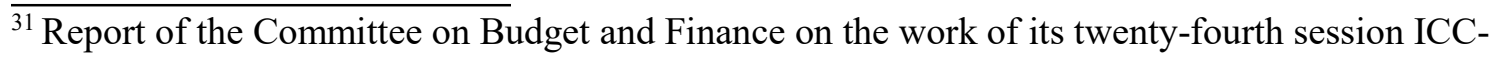
ASP/14/5. 18 June 2015. Annex I: Status of contributions as at 20 April 2015. Posted at: https://www.icccpi.int/iccdocs/asp_docs/ASP14/ICC-ASP-14-5-ENG.pdf.

${ }^{32}$ Note that the ICC started investigation into the situation in Georgia, the first non-African country. 33 “Al Bashir's escape: why the African Union defies the ICC” The Conversation. June 15, 2015.
} 
2014. ${ }^{34}$ These episodes illustrate contestation, but also demonstrate that basic principles of ICL have broad, passionate support.

It is clear that the ICC faces opposition to how it has attempted to enforced ICL norms from some important sources. The United States, for instance, has said that Americans will never come under the ICC jurisdiction, and its non-ratification along with its UNSC veto power virtually ensures that result. Six of the ten most populous states in the world are not members, ${ }^{35}$ nor are the four most militarily powerful. ${ }^{36}$ Three of the five permanent members of the Security Council and four states under investigation are not members, ${ }^{37}$ raising questions about how the ICC can do its work without on-the-ground cooperation. The claim that international criminal law norms have taken firm hold among states world-wide is therefore debatable.

Despite all of the foregoing, however, we do believe that they have. Despite arguments over jurisdiction, no actor claims that genocide, crimes against humanity, war crimes, and gross human rights violations are not the legitimate concerns of the international community. Nor do actors in the international system deny that perpetrators must in some fashion be held accountable. Indeed, current debates are about how best to implement ICL norms, and regional courts are one option; the African Union gave jurisdiction over international crimes to the African Court of Justice and Human Rights in 2010 (Du Plessis 2012). Hybrid and ad hoc courts are another option; the draft Colombian peace deal of 2016 outlined a mix of

\footnotetext{
${ }^{34}$ The statement and list of organizations can be found at Human Rights Watch website.

${ }^{35}$ Exceptions are Brazil $\left(5^{\text {th }}\right)$, Nigeria $\left(7^{\text {th }}\right)$, Bangladesh $\left(8^{\text {th }}\right)$ and Japan $\left(10^{\text {th }}\right)$.

${ }^{36}$ USA (1); Russia (2); China (3) and India (4). The rankings are by Global Firepower.

${ }^{37}$ These are Iraq, Ukraine, Sudan and Libya, although on 17 April 2014, the Government of Ukraine accepted ICC jurisdiction over alleged crimes committed on its territory from 21 November 2013 to 22
} February 2014. 
international judges with the Colombian "Special Jurisdiction for Peace." But domestic courts will and should continue to be the prime candidates to implement ICL norms, according to principles of complementarity. Indeed, if ICL norms are deeply internalized domestically, ICC prosecutions become less necessary, even though the norms are stronger than ever.$^{38}$ Strong support for ICL norms is consistent with vigorous debate over where and how to enforce these norms.

\section{Conclusions about Normative Rise, Resistance and Decline}

Norms are difficult to track and impossible to observe directly. Researchers must therefore look for evidence in words and deeds of the existence, robustness, and contestation of international norms. Even so, it is hard to say whether they are under significant duress or showing signs of healthy life. International criminal law is no exception. Compared to any pre1990 baseline, ICL norms have undergone significant development and diffusion. But how is it possible to assess whether these norms are 'robust'?

We have argued that international norm robustness ought not be confused with the values of a few states, cultures, or societies. We have advanced several reasons why norms that are held across regions and cultures of the world are more likely to be robust: they are more credible, less susceptible to interpretation as special interests, and less vulnerable to shocks that create opposition in specific regions of the world.

We urge much greater attention than is typically devoted to potential non-state nodes of norm support and resistance. Norms are more likely to be robust when they enjoy support among

${ }^{38}$ See Song (2013). 
non-state actors, including mass publics. We are not naïve enough to think that democracy prevails in all corners of the globe, but norms will be more fragile where they lack support among local populations. Especially where international criminal norms have been violated, we should not assume that governments always speak for their people. Kenyatta's behavior toward the ICC was certainly expedient, but was also constrained by the views of his people that he likely got away with murder. In the long run, norms are unlikely to be robust where non-state actors and publics do not support them. How publics, ICL advocacy groups, and rebels view ILC norms is therefore highly relevant to their robustness throughout the world.

Finally, institutionalization matters. Institutions such as treaties and courts can help stabilize expectations and support norms when those norms appear to be at risk. Normative defiance is costlier when laws and legal actors assert some degree of normative authority. It matters for ICL that ad hoc tribunals have sprouted around the world to prosecute ICL violators. It matters that a reasonably broad range of states supported the ICC by articulating and defending ICL norms, raising the costs of wanton violation. It also matters that domestic laws increasingly reflect ICL norms, including detectable moves away from blanket amnesties for violators. Norms are much harder to reverse to the extent that they are enmeshed in law and institutions at the international, regional, and local levels. Several of the ad hoc and hybrid criminal law tribunals have in fact shown they can convict, providing a plausible model for the future.

Norm contestation of ICL is still unfolding. In 2016 alone, Gambians ousted a leader who derided the ICC as "an International Caucasian Court for the prosecution and humiliation of the people of color, especially Africans" and replaced him with a new leader promising to respect international commitments. ${ }^{39}$ A national referendum rejected the Colombian peace agreement at 
least in part because the Colombian people were committed to bringing justice. ${ }^{40}$ These events emit mixed signals, but also suggest that public opinion is not irrelevant to ICL norm robustness. Robustness depends also on decentralized norm innovators, as illustrated in the case of mobile gender courts in the DRC (Lake 2014) and the mobilization of civil society support for domestic ICL in Nigerian law (Olugbuo 2016).

To conclude, there is no one way to measure the robustness of international norms, and research should consider them from all angles. Not only do we need to attend to the old concerns over measuring norms through discourse, institutions, policies or outcomes; we need also to take seriously overt threats and expressions of support for norm robustness that go well beyond states and their international performances. Norms that benefit from the support of a broad range of actors across many and diverse contexts, and that institutions also support at multiple levels are most likely to be robust. Our diversity approach is all the more relevant given the ongoing backlash that some international norms are experiencing. In considering a concept as hard to pin down as norm strength, it is particularly important to understand its broad bases of support and opposition.

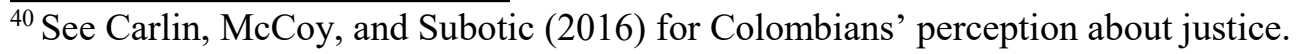




\section{Figures}

Figure 1: State attention to ICC Crimes in the UN: Number of UNGA resolutions mentioning ICC crimes, 1993-2013.

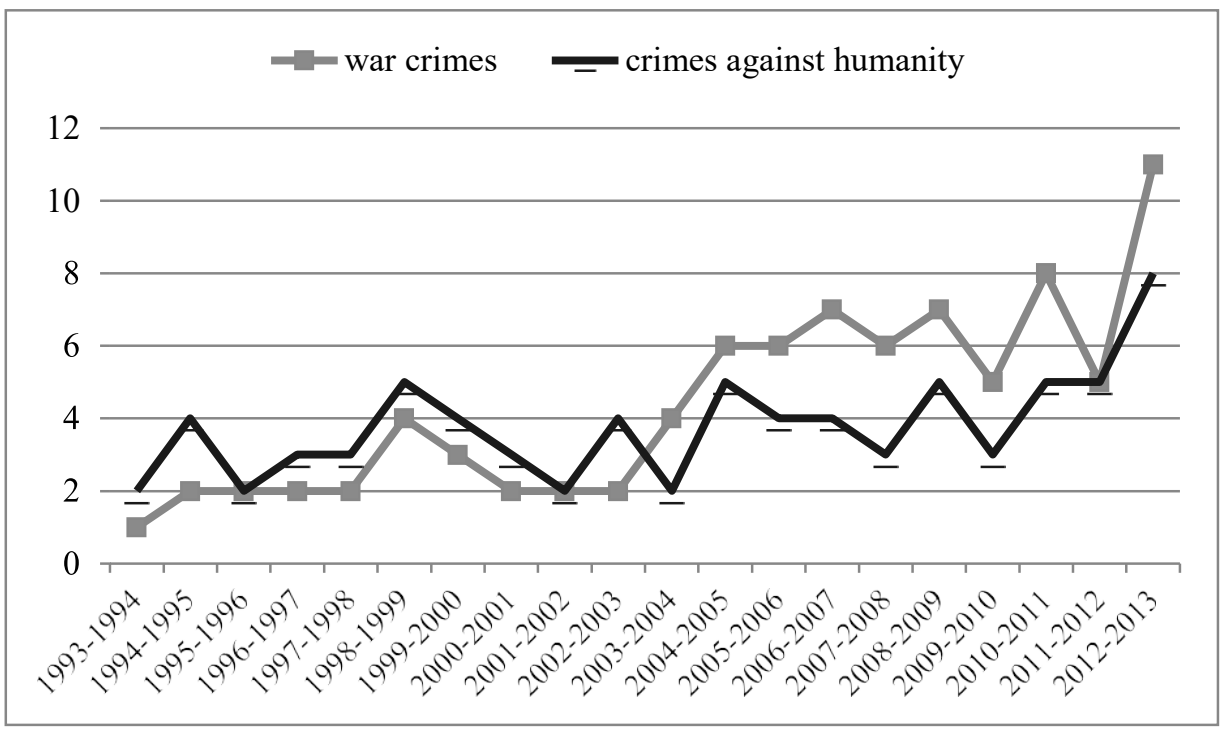

Source: Authors' database; based on resolutions at http://www.un.org/depts/dhl/resguide/gares en.shtml 
Figure 2: Rebels' Words - Political Demands and Humanitarian References

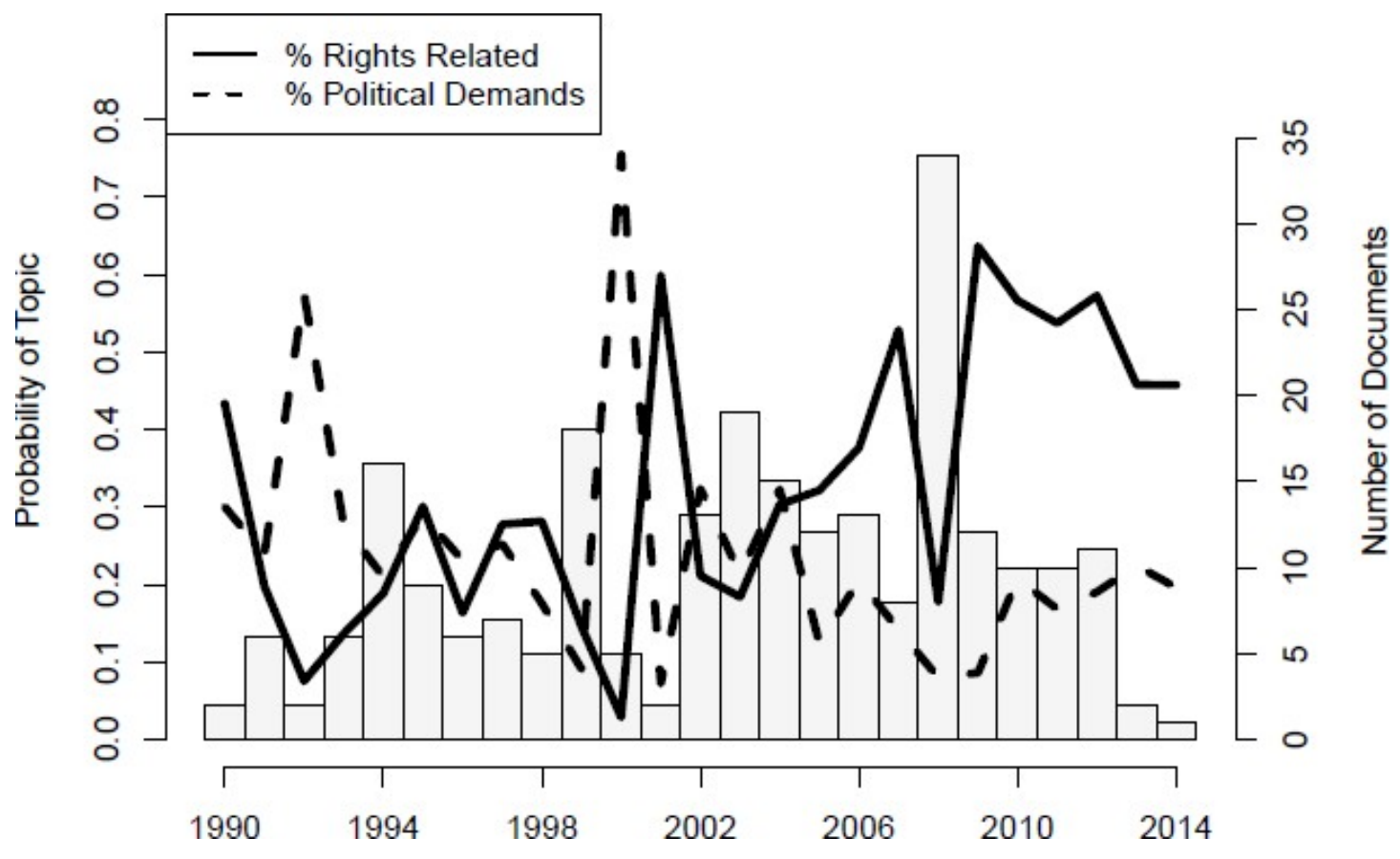


Figure 3: Accountability Effort: Conviction Rates in International Criminal Tribunals

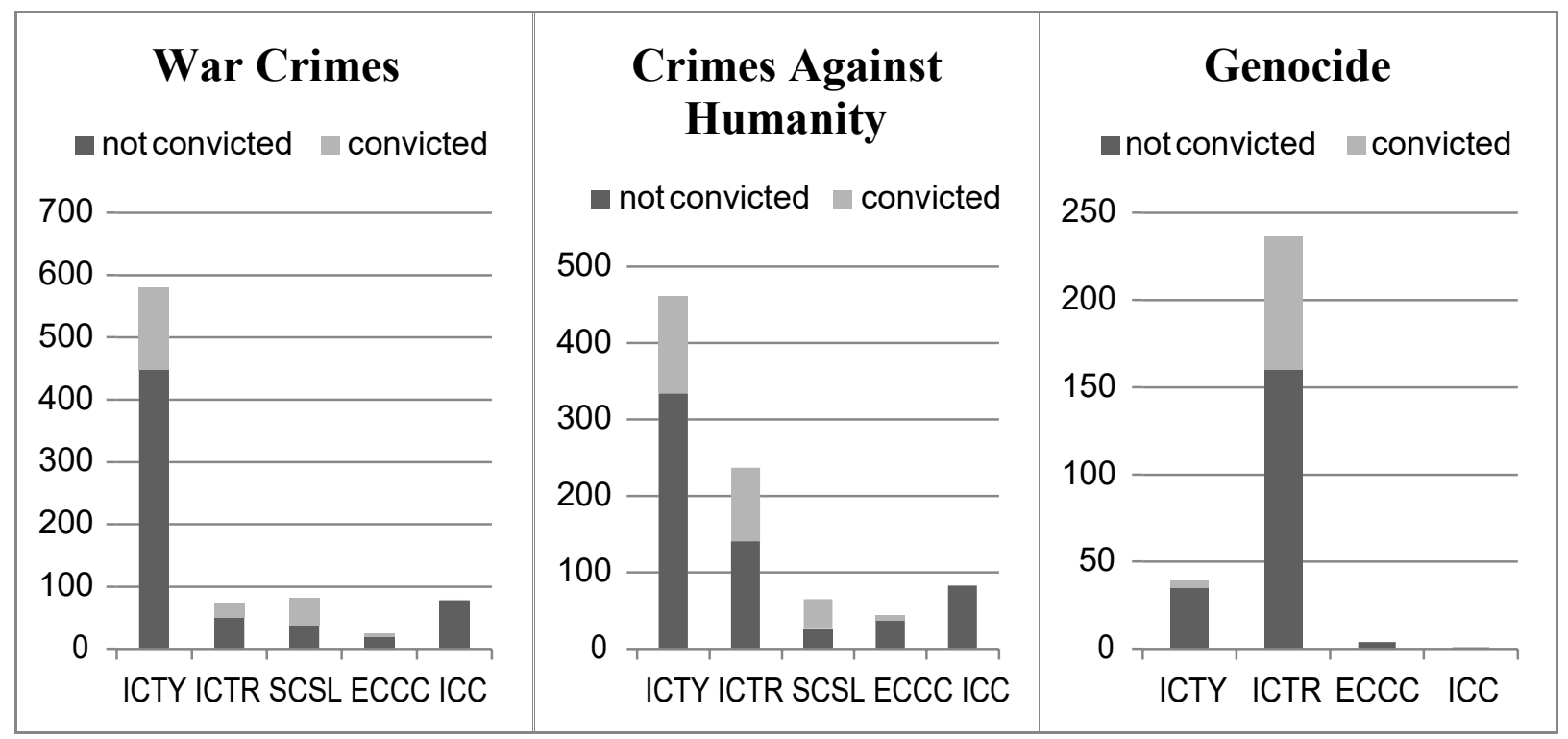

Source: estimated from International Criminal Tribunals: Visual Overview. Leitner Center for International Law and Justice. New York City. 2013. 
Figure 4: Regional Diversity of State Ratifications

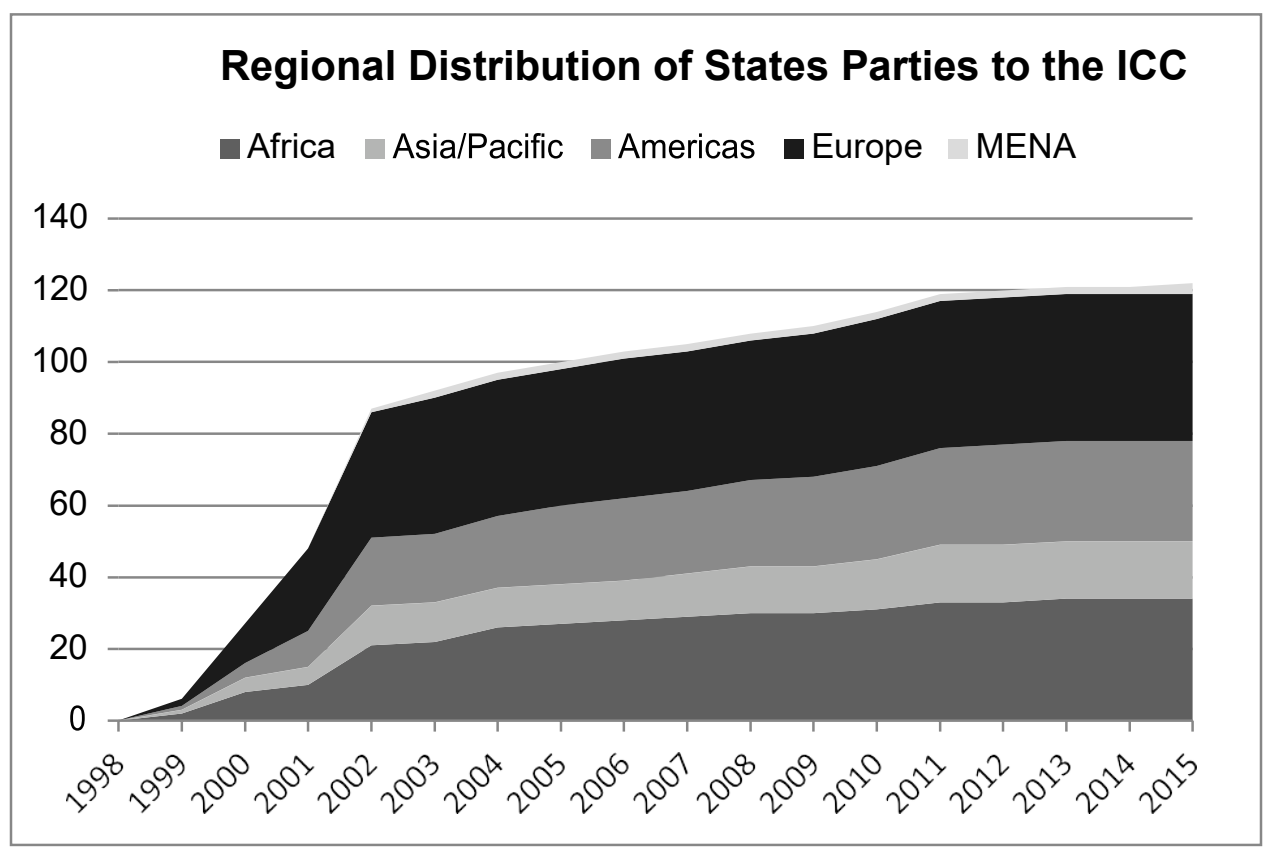


Figure 5: ICL-Consistent National Statutes, by Year and by Region
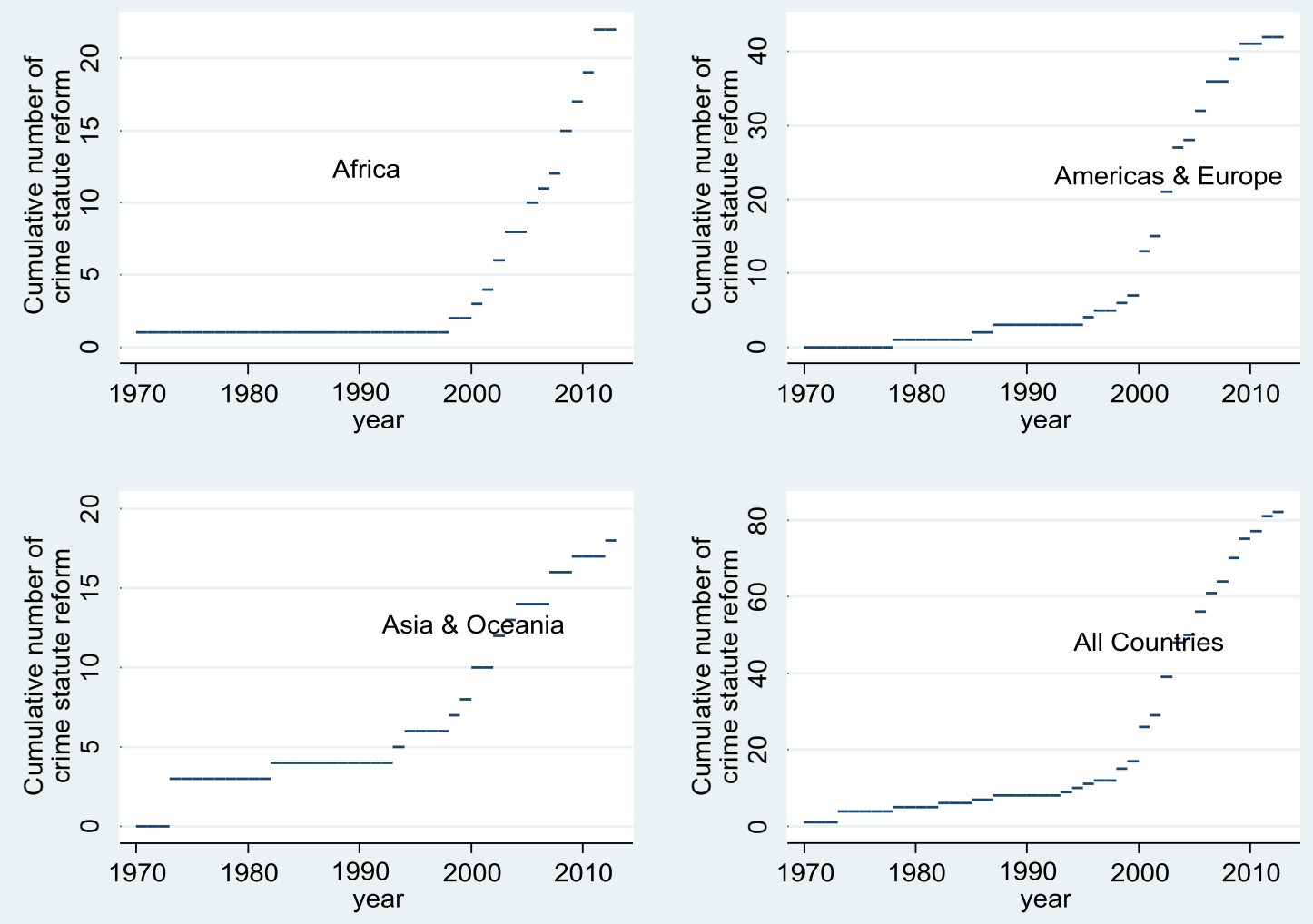


\section{References}

Acharya, Amitav. 2004. "How Ideas Spread: Whose Norms Matter? Norm Localization and Institutional Change in Asian Regionalism." International Organization 58 (2): 239-275.

Alleblas, Tessa , Eamon Aloyo, Geoff Dancy, and Yvonne Dutton. 2017. "Is the International Criminal Court biased against Africans? Kenyan victims don’t think so." MonkeyCage March 6, 2017. https://www.washingtonpost.com/news/monkeycage/wp/2017/03/06/is-the-international-criminal-court-biased-against-africanskenyan-victims-dont-think-so/?utm_term=.c72b48e615be

Bass, Gary. 2002. Stay the Hands of Vengeance: The Politics of War Crime Tribunals. Princeton University Press.

Badescu, Cristina G, and Thomas G Weiss. 2010. "Misrepresenting R2P and advancing norms: An alternative spiral?" International Studies Perspectives 11 (4): 354-374.

Bassiouni, M. Cherif. 2013. Introduction to international criminal law. 2nd rev. ed. Leiden: Martinus Nijhoff Publishers.

Bosco, David L. 2014. Rough Justice : the International Criminal Court in a World of Power Politics. Oxford University Press.

Burke-White, William W. 2008. "Proactive Complementarity: The International Criminal Court and National Courts in the Rome System of Justice." Harvard International Law Journal 49 (1): 53-108.

Carlin, Ryan, Jennifer McCoy, and Jelena Subotic. 2016. "Legitimacy Deficits in Colombia's Peace Talks: Elites, Trust, and Support for Transitional Justice." United States Agency for International Development (USAID) Research and Innovation Grants Working Papers Series, February 8. https://gsi.gsu.edu/dilemmas-of-transitional-justice-in-colombia/.

Cassese, Antonio. 2013. Cassese's International Criminal Law. Edited by Paola Gaeta, L. Baig, 40 
M. Fan, Christopher Gosnell and A. Whiting. Third edition / revised by Antonio Cassese, 
Paola Gaeta, Laurel Baig, Mary Fan, Christopher Gosnell and Alex Whiting. ed: Oxford University Press.

Charnysh, Volha, Paulette Lloyd, and Beth A. Simmons. 2015. "Frames and consensus formation in international relations: The case of trafficking in persons." European Journal of International Relations 21 (2):323-351.

Charron, Andrea. 2011. UN Sanctions and Conflict: Responding to Peace and Security Threats. New York: Routledge.

Checkel, Jeffrey. 1997. "International norms and domestic politics: bridging the rationalistconstructivist divide." European Journal of International Relations 3 (4):473-495.

Checkel, Jeffrey. 1999. "Norms, institutions, and national identity in contemporary Europe." International Studies Quarterly 43:83-114.

Cortell, Andrew, and James Davis. 1996. "How do international institutions matter? the domestic impact of international rules and norms." International Studies Quarterly 40:451-478.

Cortell, Andrew, and James Davis. 2005. "When norms clash: international norms, domestic practices, and Japan's internalisation of the GATT/WTO." Review of International Studies 31 (01): 3-25.

Crabtree, Steve, and Bob Tortora. 2009. "Lacking Faith in Judiciary, Kenyans Lean Toward The Hague." Gallup Poll News Service.

Drew, Kostic. 2011. "Whose Crime it is Anyway? The International Criminal court and the Crime of Aggression." Duke Journal of Comparative and International Law 22:109-425.

Du Plessis, Max. 2012. "Implications of the AU decision to give the African Court jurisdiction over international crimes." Institute for Security Studies (Paper No. 235). 
Dunoff, Jeffrey L., and Joel P. Trachtman. 1999. "The Law and Economics of Humanitarian Law Violation in Internal Conflict." American Journal of International Law 93 (2):394-409. Economist. 2012. "Public Opinion in Kenya: Politics and Justice."

European Council. 2002. "European Council Conclusions on the International Criminal Court." 30 September. https://www.consilium.europa.eu/uedocs/cmsUpload/ICC34EN.pdf.

Fukuda-Parr, Sakiko, and David Hulme. 2011. "International Norm Dynamics and the "End of Poverty": Understanding the Millennium Development Goals." Global Governance 17 (1): 17-36.

Gelpi, Christopher. 1997. "Crime and Punishment: The Role of Norms in Crisis Bargaining." American Political Science Review 91 (2):339-360.

Glasius, Marlies. 2006. The International Criminal Court : a Global Civil Society Achievement. New York: Routledge.

Goertz, Gary, and Paul F. Diehl. 1992. "Toward a Theory of International Norms: Some Conceptual and Measurement Issues." The Journal of Conflict Resolution 36 (4):634664.

Hafetz, Jonathan. 2016. "China and the International Criminal Court: Power and Justice Revisited." In Chinese (Taiwan) Yearbook of International Law and Affairs, Volume 32 (2014), 32-57. Brill.

Heyder, Corinna. 2006. "The U.N. Security council's referral of the crimes in Darfur to the international criminal court in light of U.S. opposition to the court : implications for the international criminal court's functions and status." Berkeley Journal of International Law 24 (2):650-671. 
Hovil, Lucy. 2011. A Poisoned Chalice? Local Civil Society and the International Criminal Court's Engagement in Uganda. In International Justice in Africa: International Refugee Rights Initiative.

Hovil, Lucy, and Joanna Quinn. 2005. "Peace First, Justice Later: Traditional Justice in Northern Uganda." Refugee Law Project Working Paper No.17.

Human Rights First. 2004. The Role of Human Rights NGOs in Relation to ICC Investigations. In Discussion Paper. Hague.

Hurd, Ian. 2015. "Torture and the Politics of Legitimation in International Law." In The Legitimacy of International Human Rights Regimes : Legal, Political and Philosophical Perspectives, edited by Andreas Follesdal, Johan Karlsson Schaffer and Geir Ulfstein, 165-189. Cambridge: Cambridge University Press.

Hyde, Susan D. 2011. The Pseudo-democrat's Dilemma : Why Election Observation Became an International Norm. Ithaca: Cornell University Press.

ICC. 2014a. Statement of the Prosecutor of the International Criminal Court, Fatou Bensouda, on the status of the Government of Kenya's cooperation with the Prosecution's investigations in the Kenyatta case. In Press Release : 05/12/2014.

ICC. 2014b. Statement of the Prosecutor of the International Criminal Court, Fatou Bensouda, on the withdrawal of charges against Mr. Uhuru Muigai Kenyatta. In Press Release : 05/12/2014: Office of the Prosecutor, International Criminal Court.

Jia, Bing Bing. 2006. "China and the International Criminal Court: the current situation." Singapore Year Book of International Law 10:87.

Jo, Hyeran. 2015. Compliant Rebels: Rebel Groups and International Law in World Politics. New York: Cambridge University Press. 
Jo, Hyeran, and Beth A Simmons. 2016. "Can the International Criminal Court Deter Atrocity? An Analysis of Violence against Civilians in Civil Wars." International Organization 70 (3): 443-475.

Kaye, David. 2013. "The Council and the Court: Improving Security Council Support of the International Criminal Court." UC Irvine School of Law Research Paper (2013-127). Kelley, Judith. 2008. "Assessing the Complex Evolution of Norms: The Rise of International Election Monitoring." International Organization 62 (2): 221-255.

Kelley, Judith. 2009. "D-Minus Elections: The Politics and Norms of International Election Observation." International Organization 63 (4): 765-787.

Kelley, Judith G. 2007. "Who Keeps International Commitments and Why? The International Criminal Court and Bilateral Nonsurrender Agreements." American Political Science Review 101 (3): 573-589.

Kersten, Mark. 2016. "New Leadership in the Gambia is Good News for the International Criminal Court." Justice in Conflict, December 2. https://justiceinconflict.org/2016/12/02/new-leadership-in-the-gambia-is-good-news-forthe-international-criminal-court/.

Kratochwil, Friedrich, and John Gerard Ruggie. 1986. "International organization: a state of the art on an art of the state." International Organization 40 (4): 753-775.

Lake, Milli. 2014. "Organizing Hypocrisy: Providing Legal Accountability for Human Rights Violations in Areas of Limited Statehood." International Studies Quarterly 58 (3): 515526.

Legro, Jeffrey W. 1997. "Which norms matter? Revisiting the "failure" of internationalism." International Organization 51 (1): 31-63. 
Lekalake, Rorisang, and Stephen Buchanan-Clarke. 2015. Support for the International Criminal Court in Africa: Evidence from Kenya. Afrobarometer Policy Paper no.23. http://afrobarometer.org/publications/pp23-support-international-criminal-court-africaevidence-kenya.

Markowitz, Harry M. 1968. Portfolio Selection: Efficient Diversification of Investments. New Haven: Yale University Press.

Matthews, Max W. 2008. "Tracking the emergence of a new international norm: the responsibility to protect and the crisis in Darfur." Boston College International and Comparative Law Review 31 (1): 137-152.

McKeown, Ryder. 2009. "Norm Regress: US Revisionism and the Slow Death of the Torture Norm." International Relations 23 (1): 5-25.

Morrow, James D. 2014. Order within Anarchy: The Laws of War as an International Institution. New York: Cambridge University Press.

Mueller, Susanne D. 2014. "Kenya and the International Criminal Court (ICC): politics, the election and the law." Journal of Eastern African Studies 8 (1): 25-42.

Nichols, Lionel. 2015. The International Criminal Court and the End of Impunity in Kenya. Cham: Springer International Publishing AG.

Nouwen, Sarah M. H. 2013. Complementarity in the Line of Fire : the Catalysing Effect of the International Criminal Court in Uganda and Sudan. Cambridge, UK: Cambridge University Press.

Nouwen, Sarah, and Wouter Werner. 2011. "Doing Justice to the Political: The International Criminal Court in Uganda and Sudan." European Journal of International Law 21 (4): 941-965. 
Olugbuo, Benson Chinedu. 2016. "Acceptance of International Criminal Justice in Nigeria: Legal Compliance, Myth or Reality?" In After Nuremberg: Exploring Multiple Dimensions of the Acceptance of International Criminal Justice, edited by Susanne Buckley-Zistel, Friederike Mieth and Marjana Papa. Nuremberg: International Nuremberg Principles Academy.

Panke, Diana, and Ulrich Petersohn. 2012. "Why international norms disappear sometimes." European Journal of International Relations 18 (4): 719-742.

Percy, Sarah V. 2007. "Mercenaries: Strong Norm, Weak Law." International Organization 61 (2):367-397.

Pham, Phuong, Patrick Vinck, Mychelle Balthazard, Sokhom Hean, and Eric Stover. 2009. "So We Will Never Forget: A Population-Based Survey on Attitudes about Social Reconstruction and the Extraordinary Chambers in the Courts of Cambodia." Human Rights Center, University of California, Berkeley.

Pham, Phuong, Patrick Vinck, Eric Stover, Andrew Moss, Marieke Wierda, and Richard Bailey. 2007. "When the War Ends: A Population-Based Survey on Attitudes about Peace, Justice and Social Reconstruction in Northern Uganda.” Human Rights Center, University of California, Berkeley.

Pham, Phuong, Patrick Vinck, and Eric Stover. 2005. "Forgotten Voices: A Population-Based Survey of Attitudes about Peace and Justice in Northern Uganda.” Human Rights Center, University of California, Berkeley.

Price, Richard. 2006. "Detecting Ideas and their Effects." in The Oxford Handbook of Contextual Political Analysis, edited by Robert E. Goodin and Charles Tilly, Oxford: Oxford University Press. 
Ramanathan, Usha. 2014. "The Surprising Impact of the Rome Statute in India" OpenGlobalRights. 7 November. https://www.opendemocracy.net/openglobalrights/usharamanathan/surprising-impact-of-rome-statute-in-india.

Raymond, Gregory A. 1997. "Problems and prospects in the study of international norms." International Studies Quarterly 41: 205-245.

Risse, Thomas, Steve C. Ropp, and Kathryn Sikkink. 1999. The Power of Human Rights: International Norms and Domestic Change, Cambridge, UK: Cambridge University Press.

Schabas, William. 2006. The UN International Criminal Tribunals. Cambridge, UK: Cambridge University Press.

Scheffer, David. 2012. All the Missing Souls. Princeton, N.J.: Princeton University Press. Schroeder, Michael, and Alana Tiemessen. 2014. "Transnational Advocacy for Accountability: From Declarations of Anti-Impunity to Implementing the Rome Statute." In Implementation and World Politics: How International Norms Change Practice, edited by Alexander Betts and Phil Orchard, 50-67. Oxford: Oxford University Press.

Sewall, Sarah, and Carl Kaysen. 2000. The United States and the International Criminal Court: National Security and International Law. Rowman \& Littlefield Publishers.

Shraga, Daphna. 2011. "The Security Council and Human Rights - From Discretion to Promote to Obligation to Protect." In Securing Human Rights: Achievements and Challenges of the UN Security Council, edited by Bardo Fassbender, 8-35. New York: Oxford University Press.

Sikkink, Kathryn. 2011. The Justice Cascade: How Human Rights Prosecutions Are Changing World Politics. New York: W. W. Norton \& Company.

Simmons, Beth A., and Allison Marston Danner. 2010. "Credible Commitments and the 
International Criminal Court." International Organization 64 (2): 225-256. 
Slaughter, Anne-Marie, and William Burke-White. 2006. "The Future of International Law is Domestic (or, The European Way of Law)." Harvard International Law Journal 47 (2): $327-52$.

Song, Sanghyun. 2013. "Preventive Potential of the International Criminal Court." Asian Journal of International Law 3 (2): 203-213.

United States Bureau of Justice Statistics, 2016. "What is the probability of conviction for felony defendants?" Office of Justice Programs. Retrieved on 15 November 2016. http://www.bjs.gov/index.cfm?ty=qa\&iid=403.

Van Leeuwen, Sophie. 2015. "Many ICC Countries Are Not Paying” Justice Hub. 23 June. https://justicehub.org/article/many-icc-countries-are-not-paying.

Vinck, Patrick, Phuong Pham, Suliman Baldo, and Rachel Shigekane. 2008. "Living with Fear: A Population-Based Survey on Attitudes about Peace, Justice and Social Reconstruction in Eastern Congo." Berkeley, CA: Human Rights Center, University of California, Berkeley.

Vinck, Patrick, and Phuong Pham. 2010. "Building Peace, Seeking Justice: A Population-based survey on attitudes about accountability and social reconstruction in the Central African Republic" Berkeley, CA: Human Rights Center, University of California, Berkeley.

Voeten, Erik. 2013. "Public Opinion and the Legitimacy of International Courts." Theoretical Inquiries in Law 14 (2):411-436.

Wotipka, Christine Min, and Francisco O. Ramirez. 2008. "World Society and Human Rights: An Event History Analysis of the Convention on the Elimination of all forms of Discrimination Against Women." In The Global Diffusion of Markets and Democracy, 
edited by Beth A Simmons, Frank Dobbin and Geoffrey Garrett, 303-343. New York: Cambridge University Press.

Zimmermann, Lisbeth, and Nicole Deitelhoff. 2016. "Things We Lost in the Fire: How Different Types of Contestation Affect the Robustness of International Norms."

Zwingel, Susanne. 2012. "How Do Norms Travel? Theorizing International Women’s Rights in Transnational Perspective1." International Studies Quarterly 56 (1): 115-129. 